\title{
13. Fossilization, permineralization, coalification, carbonization and wet wood conservation
}

\subsection{Fossilization}

When remains or traces of organisms are preserved in sediments they are called fossils. The process of fossilization (syn. petrification or permineralization) begins when organisms, e.g. stems, are buried and remain in anaerobic conditions. Most petrified stems are therefore in a horizontal position. Many fossil stems were probably driftwood that was buried by fluvial sediments. Stems in upright position were more likely embedded in volcanic ashes. When supersaturated groundwater penetrates the wood, the minerals precipitate within cellular spaces and crystalize. Most frequent are calcium carbonate $\left(\mathrm{CaCO}_{3}\right)$ or silicate minerals $\left(\mathrm{SiO}_{2}\right)$. Fossilization occurs mainly in association with marine or volcanic hydrothermal water. Characteristic for fossils is the conservation of microscopic structures that can be observed on polished disks or on micro-sections. Observations on fossilized wood leads to four principal findings:

- Taxonomic classifications are still possible on well-preserved fossils.

- Assemblages of fossils (petrified wood and pollen) in stratigraphically uniform layers allow a limited reconstruction of past vegetation types.
13.1 Stem disc of a Triassic Araucarioxylon stem from a petrified forest in Arizona, USA.
- Conclusions about the seasonality of past climates are possible on the basis of the presence or absence of growth rings. Banded agates can resemble growth rings in petrified wood, but they represent periodic mineral deposits, e.g. in stalactites.

- Diagenetic processes (alteration during fossilization) can be reconstructed on the basis of the preservation of tissue and cell-wall structure, and the crystalline composition of minerals. Hyphae, barrier zones and coprolites indicate a decay under aerobic conditions, while cell-wall degradation, cell deformation and root inclusions indicate decay under anaerobic conditions before petrification. Different colors on polished discs are related to different minerals, e.g. red is related to iron, blue and transparent to silicate, green to copper and pink to manganese. Mineral composition can be quantified on a microscopic section under polarized light.

See also Taylor et al. 2009 and Selmeier 2015. 
Geological context of petrified wood

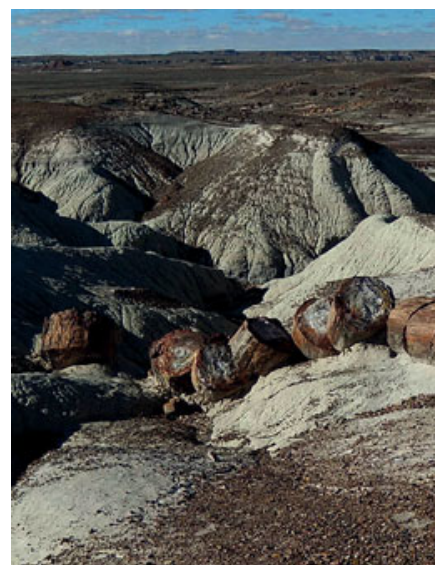

13.2 Eroded petrified stems from fluviatile sediments of the Upper Triassic, approx. 200 million years ago, Petrified Forest, Arizona, USA Photo: V. Markgraf.

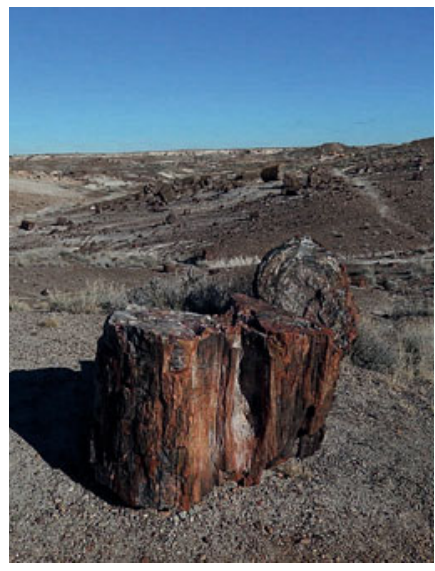

13.3 Broken and dislocated petrified stems from fluviatile sediments. Upper Triassic, approx. 200 million years ago, Petrified Forest, Arizona, USA. Photo: V. Markgraf.

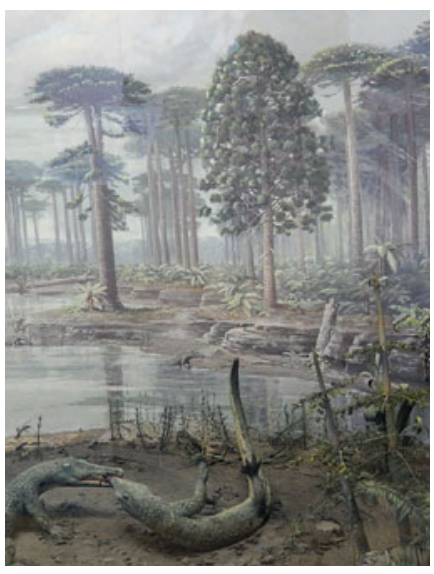

13.4 Reconstruction of the Araucaria forest at the Chinle Formation (Trias). Display at the Visitor Center of the Petrified Forest.

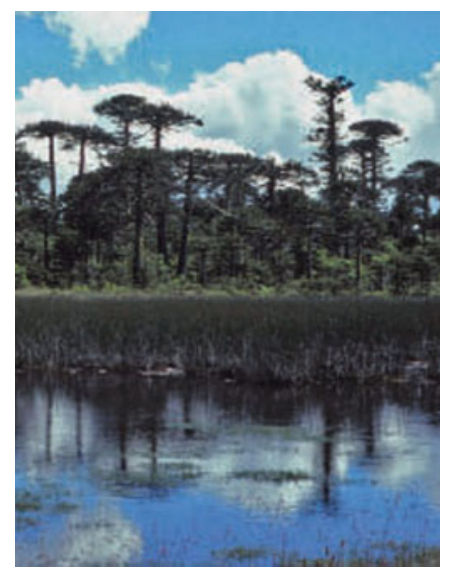

13.5 Modern Araucaria araucana forest in Patagonia, Chile.
Macroscopic aspect of polished disks

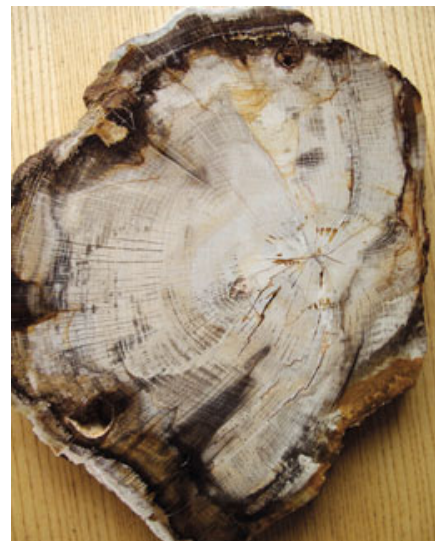

13.6 Quercoxylon sp. with distinct annual rings. Miocene, approx. 20 million years ago, Great Basin, Idaho, USA.

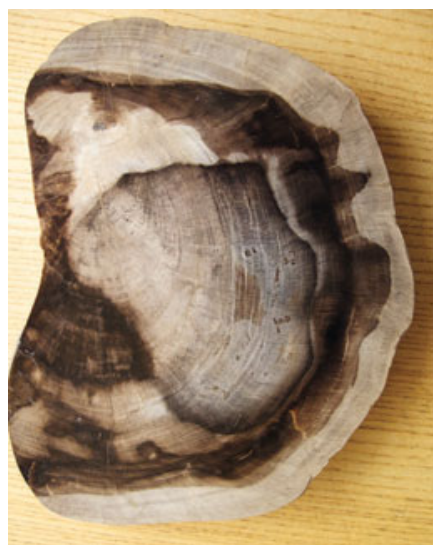

13.7 Conifer with indistinct annual rings. Miocene, approx. 20 million years ago, Great Basin, Idaho, USA.

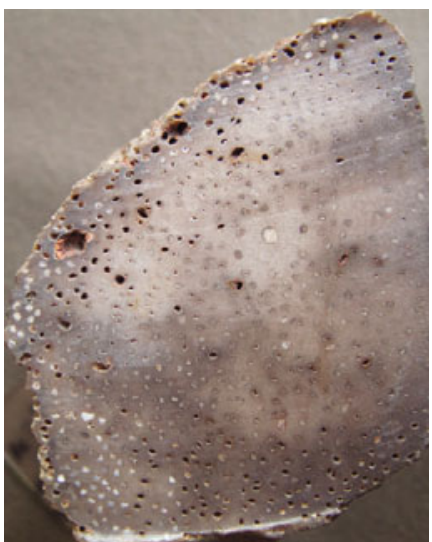

13.8 Palmoxylon sp., of unknown age and locality, with distinct vascular bundles.
Taxonomic classification of petrified wood

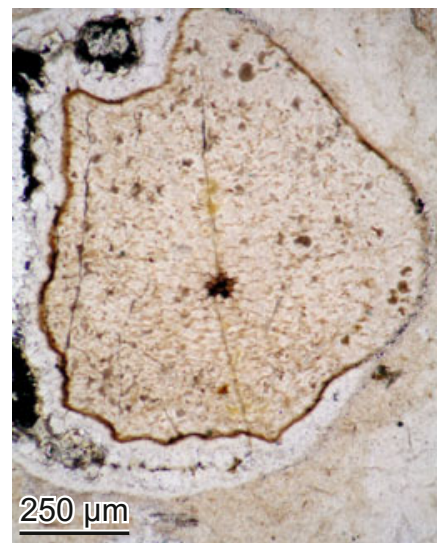

13.10 Rhynia gwynne-vaughanii, a herb with a central stele. Lower Devonian, approx. 400 million years ago, Scotland.

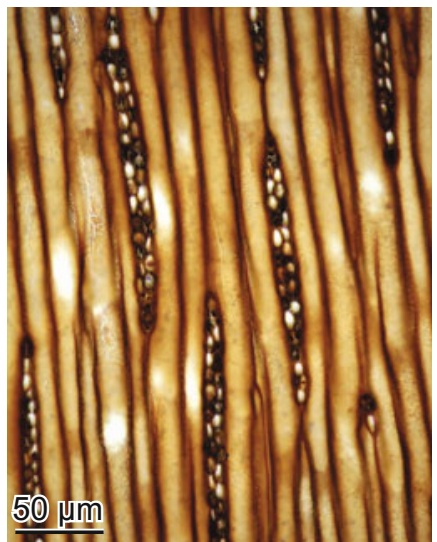

13.11 Cross section of Paradoxylon leuthardii, one of the Cordaitales without annual rings. Upper Triassic, approx. 220 million years ago, Vosges Mountains, France. Slide: R. Buxtorf.

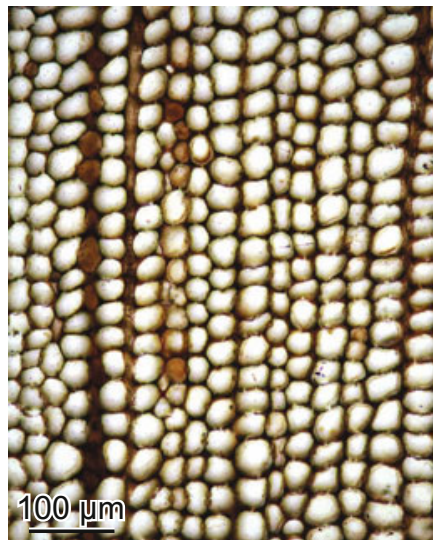

13.12 Tangential section of Paradoxylon leuthardii with biseriate rays. Upper Triassic, approx. 220 million years ago, Vosges Mountains, France. Slide: R. Buxtorf.

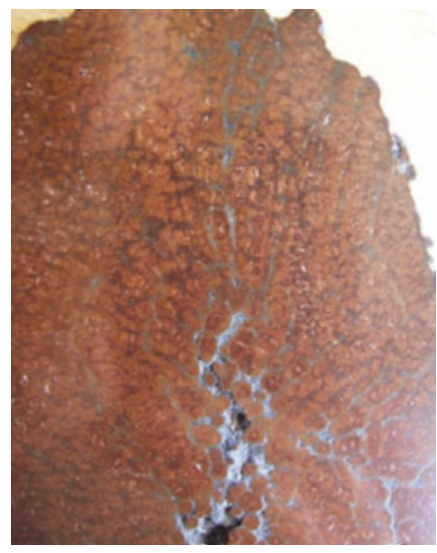

13.9 Petrified liana of unknown age and locality.

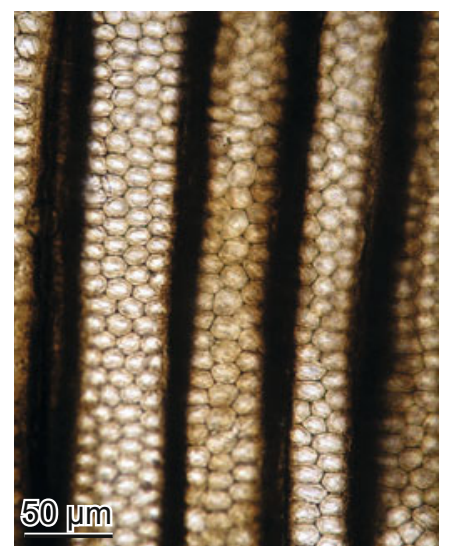

13.13 Radial section of Paradoxy lon leuthardii with multiseriate bordered pits on tracheids. Upper Triassic, approx. 220 million years ago, Vosges Mountains, France. Slide: R. Buxtorf. 
Taxonomic classification of petrified wood
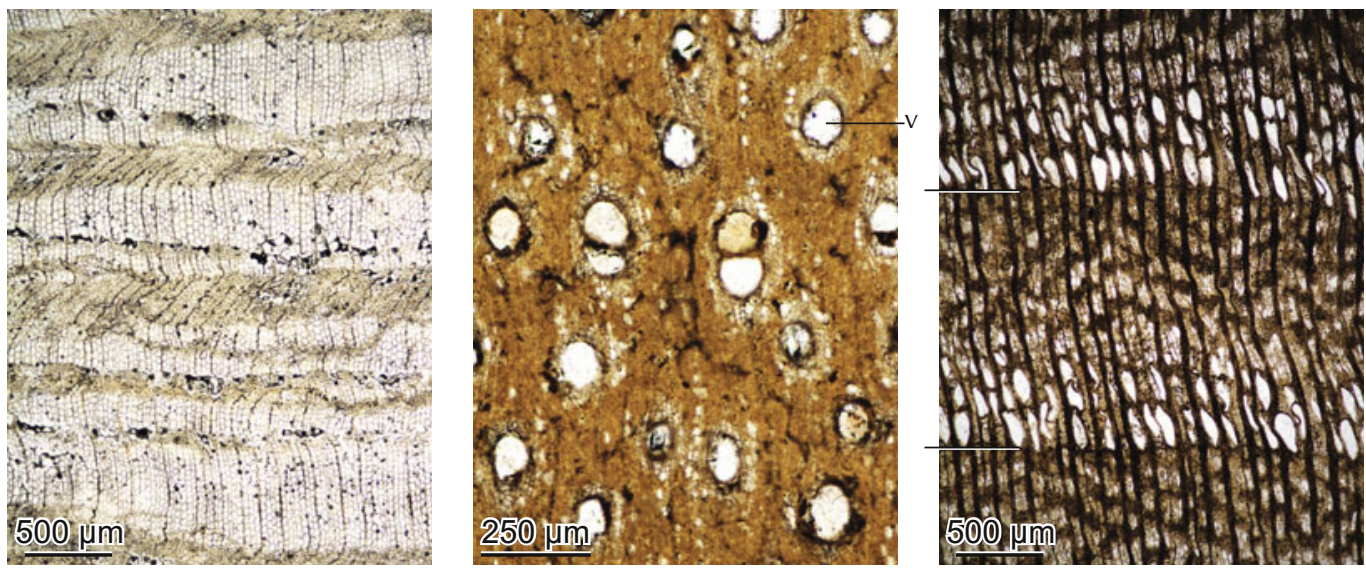

13.14 Sequoia sp. with distinct and indistinct rings. Early Oligocene, approx. 34 million years ago, Florissant, Colorado, USA

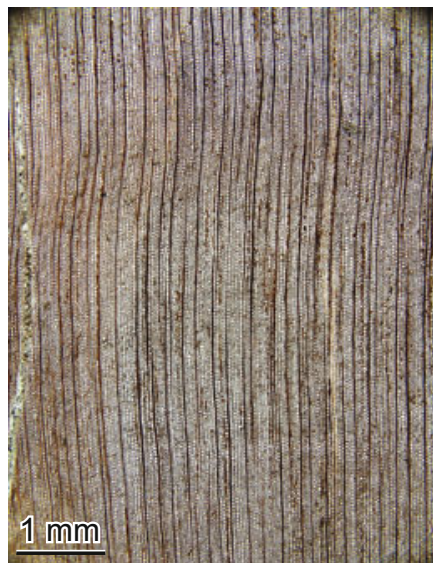

13.18 Cross section of Paradoxylon leuthardii, without growth rings, indicating tropical rain forest as habitat? Upper Triassic, approx. 220 million years ago, Vosges Mountains, France. Slide: R. Buxtorf

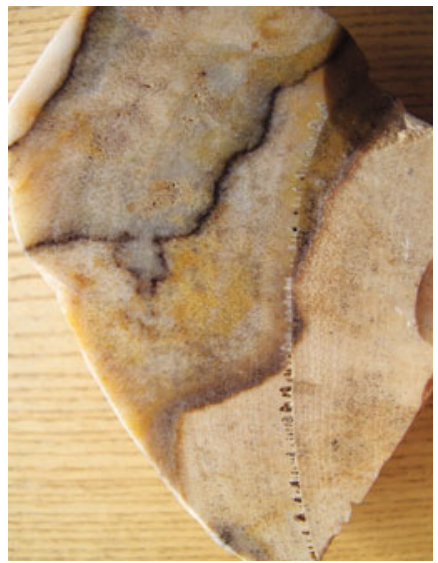

13.22 Barrier zones in a petrified stem of a eucalypt tree. Australia, age unknown.
13.15 Mimosoideae, Fabaceae, without annual rings, with paratracheal parenchyma. Oligocene, approx. 28 million years ago, Vosges Mountains, France. Slide: R. Buxtorf.

Growth rings in petrified wood
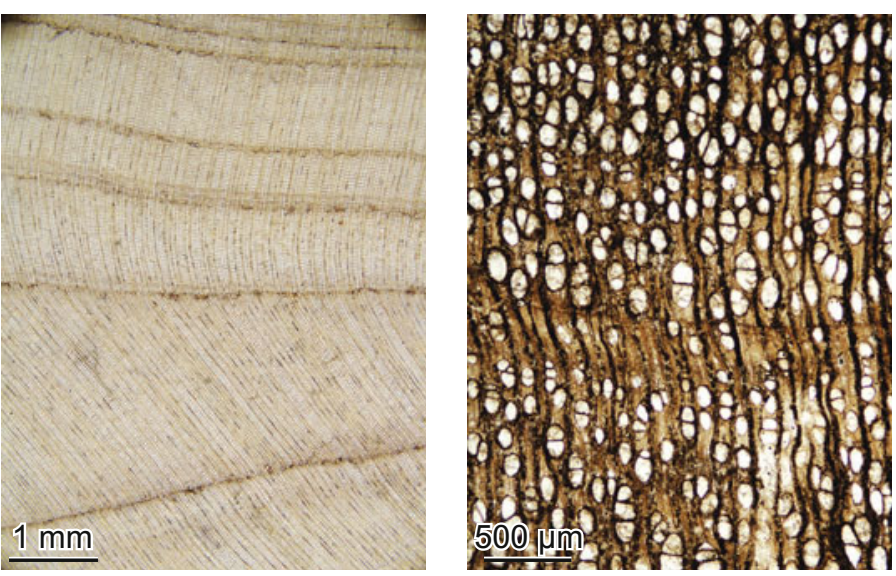

13.19 Cross section of Paradoxylon leuthardii, with growth rings, indicating seasonal climate. Upper Triassic, approx. 220 million years ago, Vosges Mountains, France. Slide: R Buxtorf.

13.20 Lauraceae cf. with growth rings, seasonal climate. Oligocene, approx. 28 million years ago, Vosges Mountains, France. Slide: R. Buxtorf.
Indicators of aerobic decay before petrification

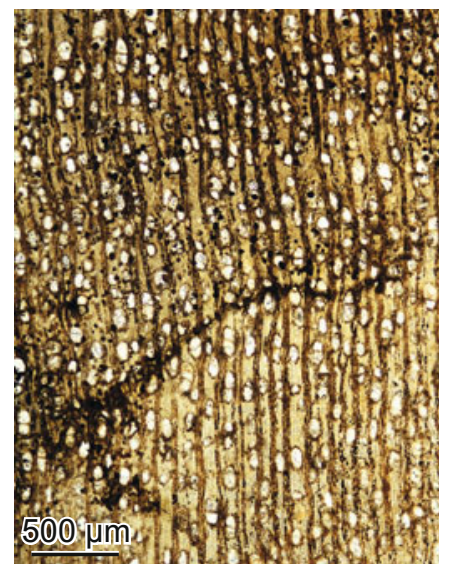

13.23 Barrier zones in a stem of a Lauraceae cf. tree. Oligocene, approx. 28 million years ago, Vosges Mountains, France. Slide: R. Buxtorf.

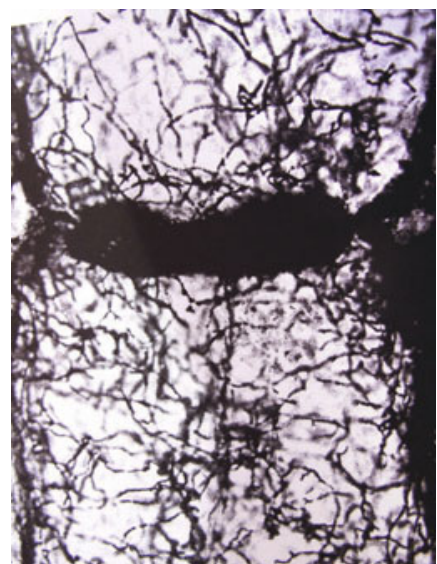

13.24 Hyphae in a vessel of a Meliaceae tree. Reprinted from Selmeier 2015.
13.16 Celtixylon of Ulmaceae, with distinct annual rings. Oligocene, approx. 28 million years ago, Vosges Mountains, France. Slide: R. Buxtorf.

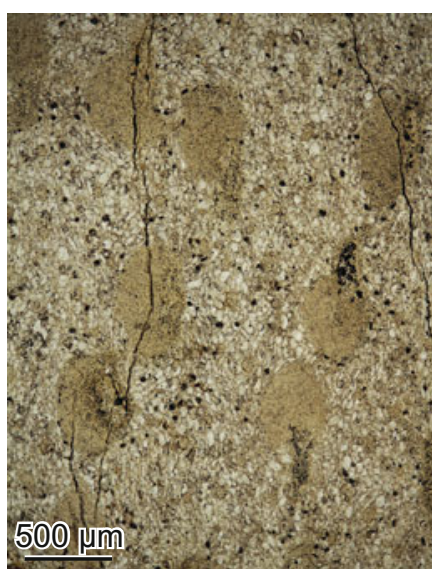

13.17 Palmoxylon, Arecaceae, with distinct lignified parts of vascular bundles. Oligocene, approx. 28 million years ago, Vosges Mountains, France. Slide: R. Buxtorf.

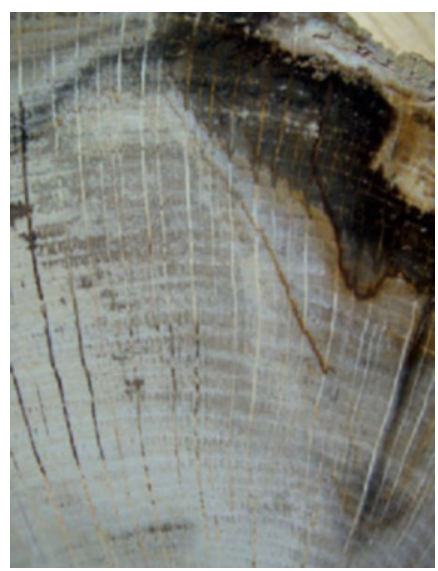

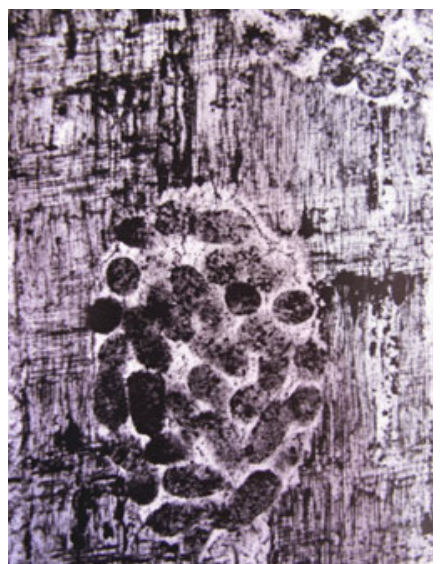

13.25 Coprolites of a beetle in a Lauraceae tree. Reprinted from Selmeier 2015. 


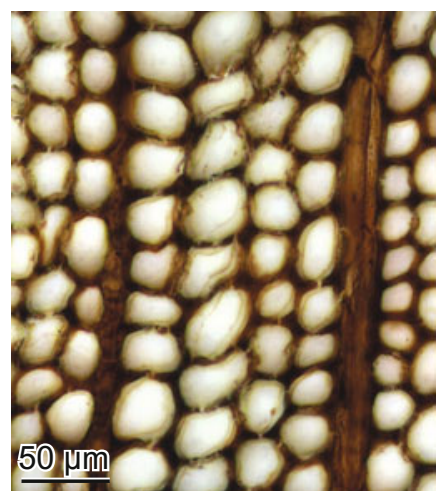

13.26 Decayed cell walls in Para doxylon leuthardii. Preserved are the thick primary walls and thin tertiary walls. Slide: R. Buxtorf.

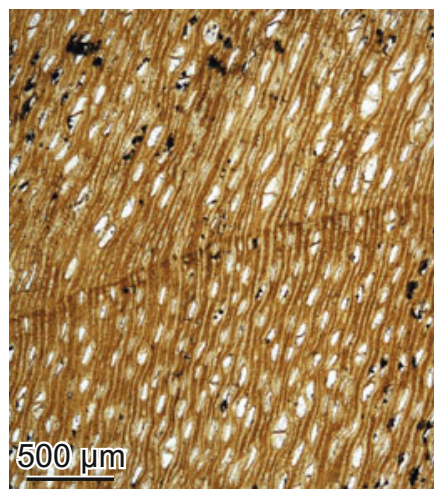

13.27 Radially compressed dicotyledonous wood. Slide: R. Buxtorf.

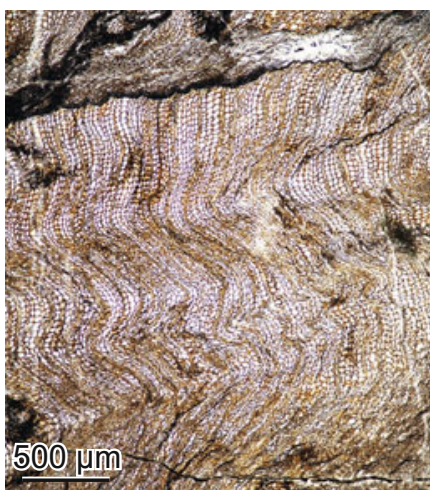

13.28 Heavily tangentially compressed wood of Paradoxylon leuthardii. Slide: R. Buxtorf.

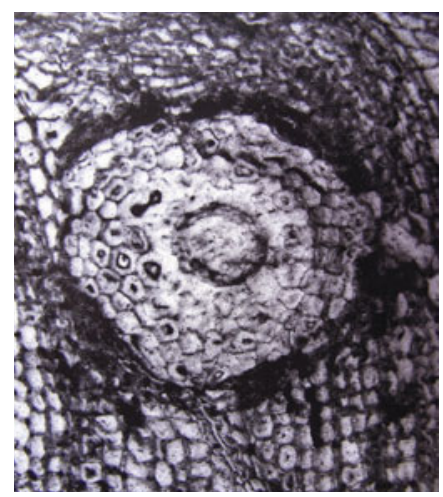

13.29 The root of a herb squeezed the soft, anaerobically decayed xylem tissue. Reprinted from Selmeier 2015

Permineralization under polarized light

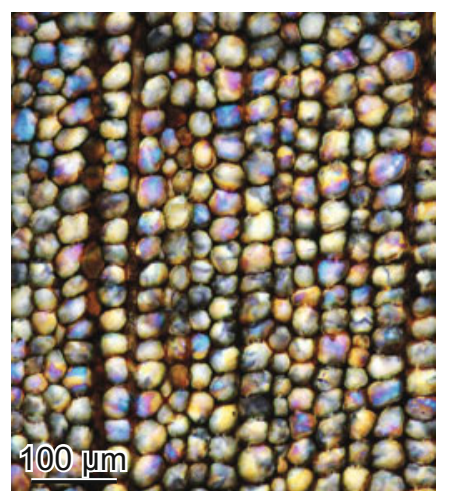

13.30 Single crystals in individual tracheids in Paradoxylon leuthardii. Slide: R. Buxtorf.

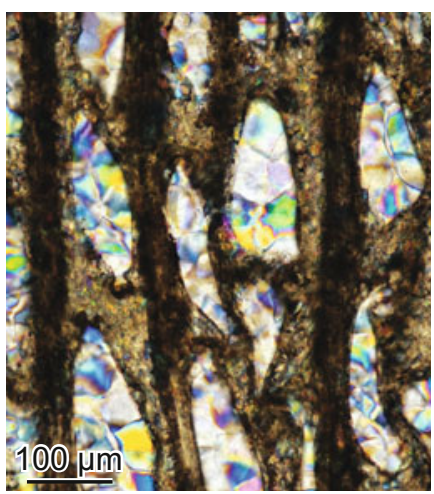

13.31 Many crystals in large earlywood vessels in Ulmaceae wood Slide: R. Buxtorf.

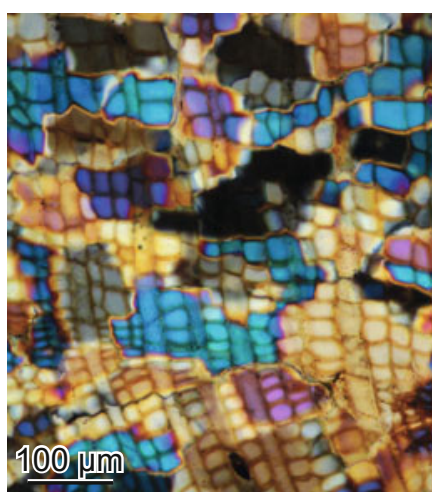

13.32 Irregular crystallization of silicates without any wood anatomical context in Ulmaceae wood. Slide: R. Buxtorf.

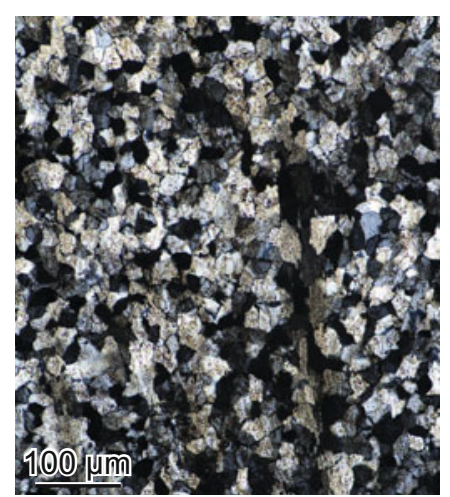

13.33 Crystallization of different minerals relating to groups of tracheids in Paradoxylon leuthardii. Slide: R. Buxtorf.

\section{2 Permineralization of archaeological artifacts}

Permineralization also takes place on metallic archaeological artifacts. The scabbards and handles of iron swords, bronze daggers and axes often contain small mineralized remains of wood. Transverse and longitudinal breaks of particles clearly show the anatomical structure. Species identification is therefore possible. If highly concentrated liquids of iron, copper or sulfur soak the wood, minerals precipitate on cell walls and preserve their structure.

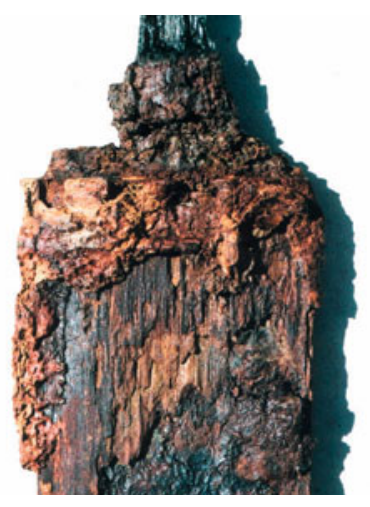

13.34 Wooden scabbard permineralized by dissolved iron. Photo: W. Tegel.
Permineralization of archaeological artifacts

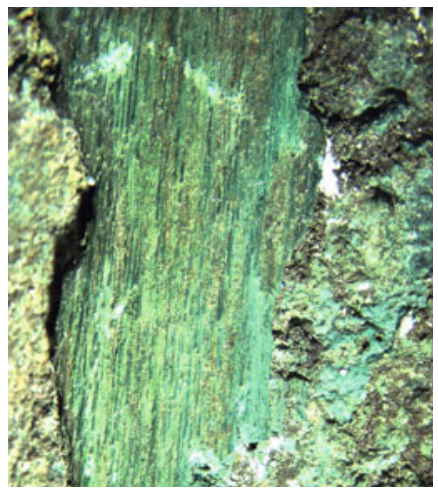

13.35 Wooden scabbard permineralized by dissolved copper. Photo: W. Tegel.

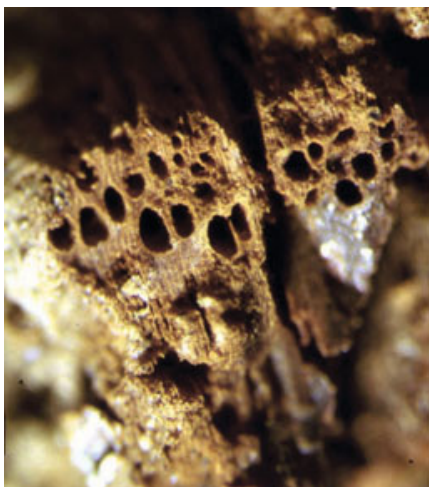

13.36 Microscopic structure of archaeological Quercus sp. wood, permineralized by iron. Photo: W. Tegel.

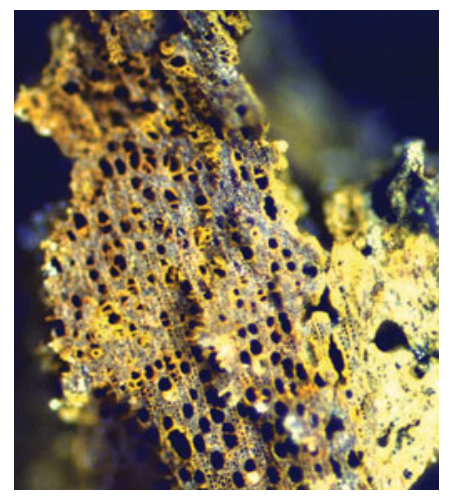

13.37 Microscopic structure of archaeological Alnus sp. wood, permineralized by sulfur. Photo: W. Tegel. 


\subsection{Coalification}

Coalification is a very slow process in which wood is transformed into coal at geological time scales. The anaerobic decay of organic substances is the first stage of coalification (see Chapter 12.2). The ratio of carbon increases during anaerobic decay processes, and the wood loses its stability. The process starts with soft wood, which under high pressure and high temperatures turns into brown coal, bituminous coal and finally anthracite. An increase in carbon content defines these grades-wood contains $50 \%$, brown coal $70 \%$ and anthracite $90 \%$ carbon. When softened logs come under mechanical pressure by sediments or ice, the thin-walled earlywood cells collapse, and the stems get deformed. Early stages of coalification are known from stems in medieval glacier deposits and late glacial clays (subfossil wood).
Remnants of wood (xylite, lignite) with well-preserved structures are frequently found in brown coal layers (Eocene to Oligocene). Genera or even species can be identified as long as the earlywood zones are not too much distorted (Dolezych 2005).

Tertiary wood is often so well preserved that even stages of cell wall decay can be recognized. However, in most cases the earlywood zones are compressed, and the corresponding ray features are difficult to observe (Dolezych 2005).
Fossil tree stump

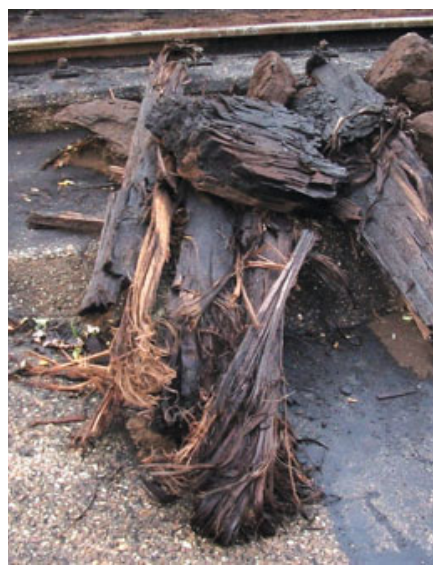

13.38 Stumps from a brown coal bed. Photo: Elbwestfale 2003, via Wikimedia Commons, CC BY-SA 3.0 .

Taxonomically and climatologically relevant features in cross sections of conifers

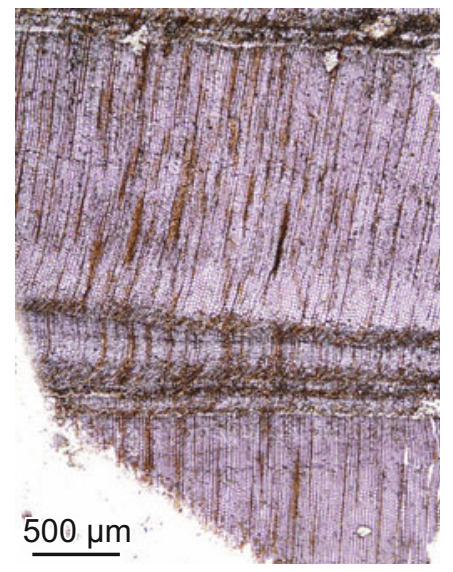

13.39 Conifer Taxodium taxodii cf. without growth zones. Oligocene, approx. 34-23 million years ago. Material: M. Dolezych.

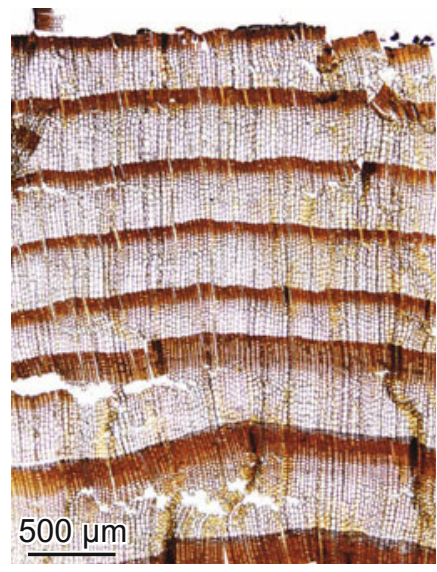

13.40 Conifer Sciadopityoxylon wettsteinii without resin ducts and distinct earlywood and latewood zones. Miocene, approx. 25-5 million years ago. Material: M. Dolezych.

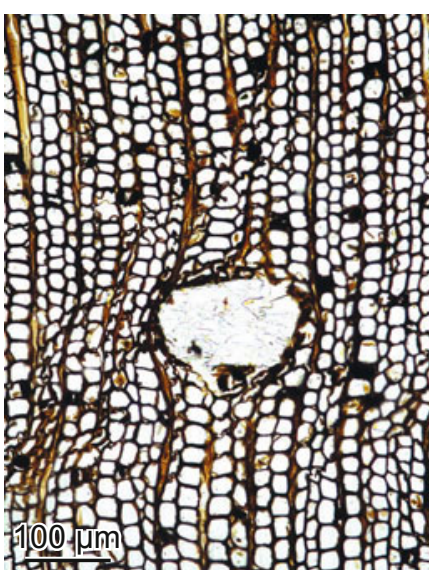

13.41 Conifer Doliostroboxylon priscum with resin ducts. Eocene, approx. 56-38 million years ago. Material: M. Dolezych.

Taxonomically relevant features in radial and tangential sections of conifers

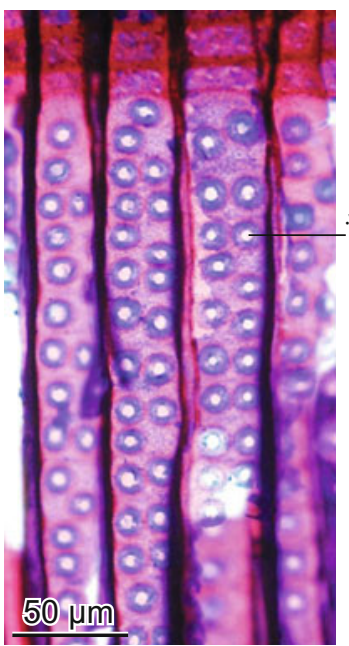

13.42 Conifer Larix decidua with biseriate tracheid pits Interglacial period, Italian Alps, >50,000 years ago.

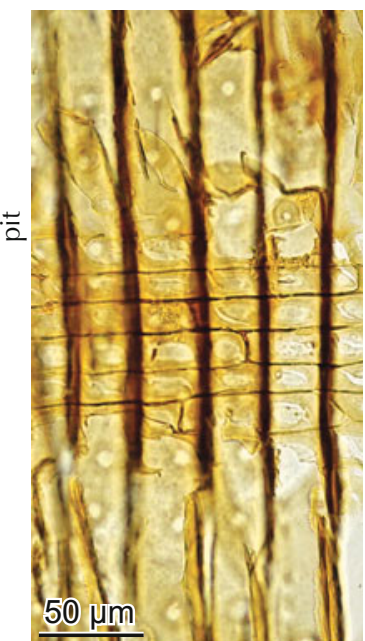

13.43 Fenestrate vessel-ray pits in the earlywood of Sciadopityoxylon wettsteinii. Miocene, approx. 25-5 million years ago. Material: M. Dolezych.

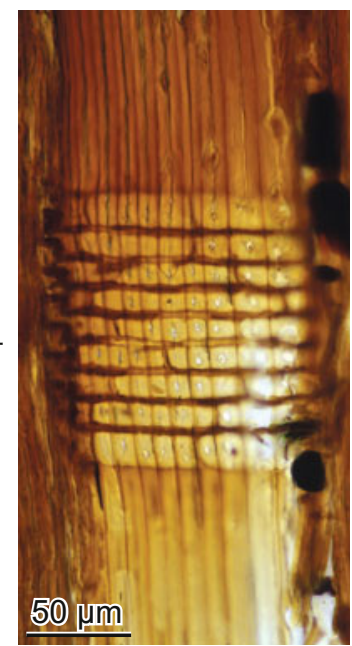

13.44 Small round pits in the latewood of Taxodium gypsacum. Miocene, approx. 25-5 million years ago. Material: M. Dolezych.

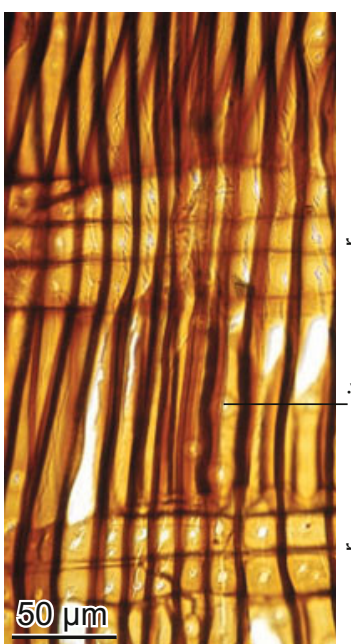

13.45 Large round pits in the early- and latewood of Doliostroboxylon priscum. Eocene, approx. 56-38 million years ago. Material: $M$ Dolezych.

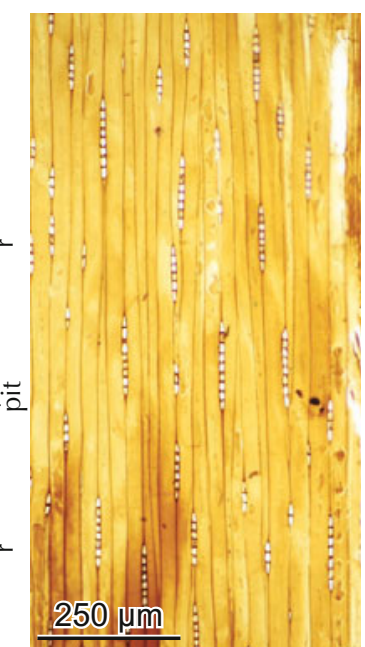

13.46 Uniseriate rays with three to ten cells in Taxodium gypsacum. Miocene, approx. 25-5 million years ago. Material: M. Dolezych. 
Cell wall decay in latewood

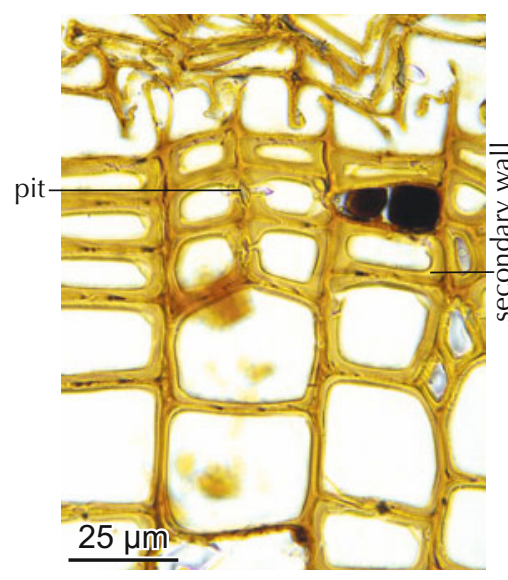

13.47 Perfectly preserved cell walls in latewood tracheids of Glyptostoapprox. 15 million years ago. Material: M. Dolezych.

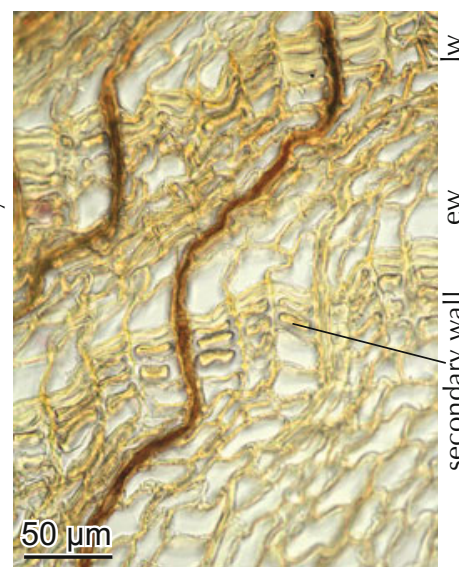

13.48 Anaerobically decayed cell decidua from the moraine of an $1400 \mathrm{AD}$

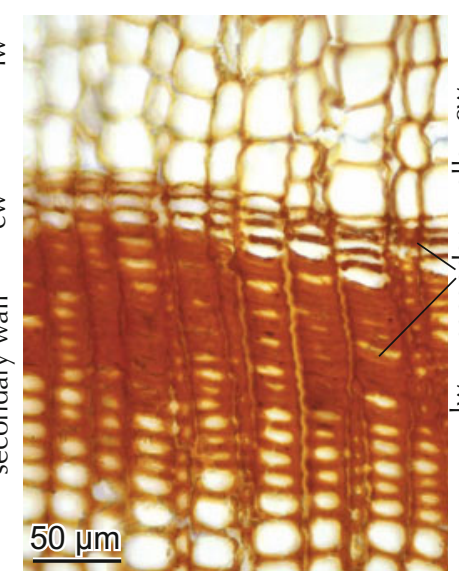

13.49 Various

ecay in the latewood zone of Materia: M. Dolezych.

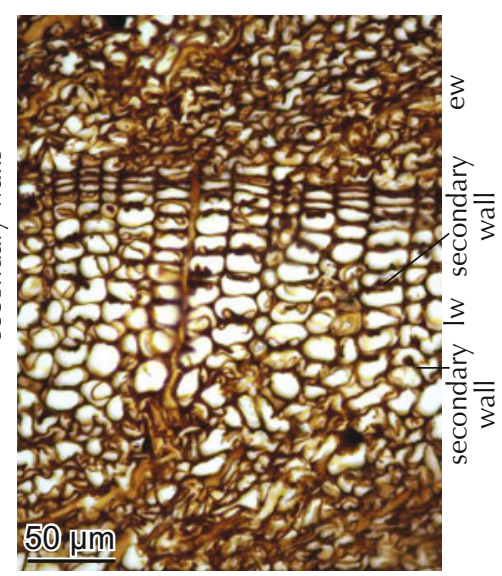

13.50 Primary and tertiary cell walls
Mechanical deformation of cells
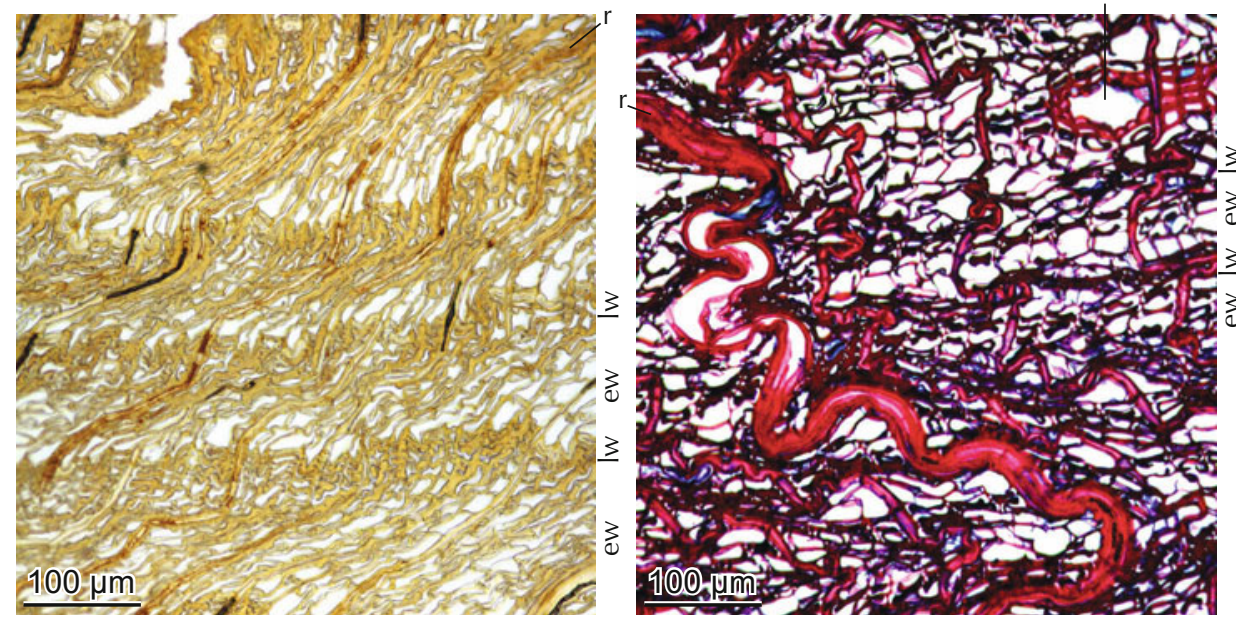

13.52 Radial compression is indicated by bent rays in wood of Larix decidua. Interglacial period,
Italian Alps, $>50,000$ years ago. Slide stained with Astrablue/Safranin.

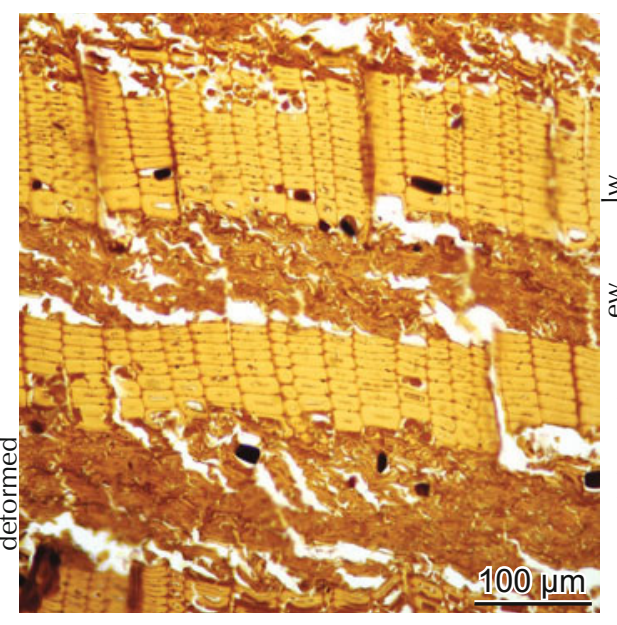

13.55 Intensively compressed earlywood zones between thick-walled latewood zones in Taxodium gypsacum. Miocene, approx.

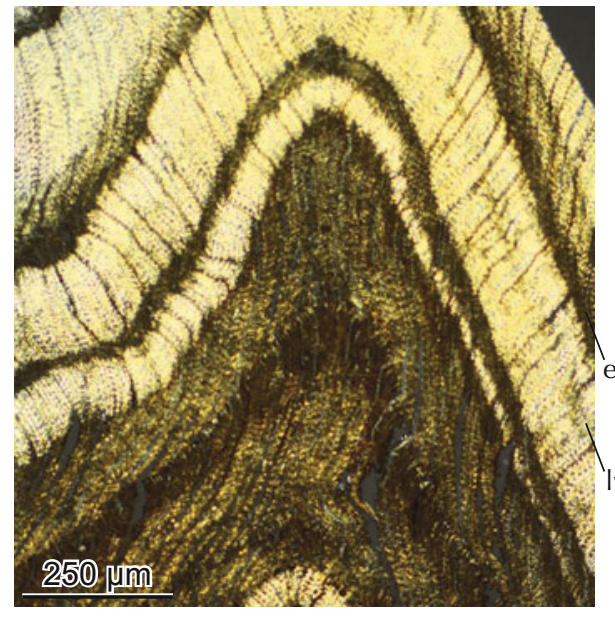

13.53 Compression in a branch of Abies alba cf. polarized light. Interglacial period, Switzerland, approx. 45,000 years ago.

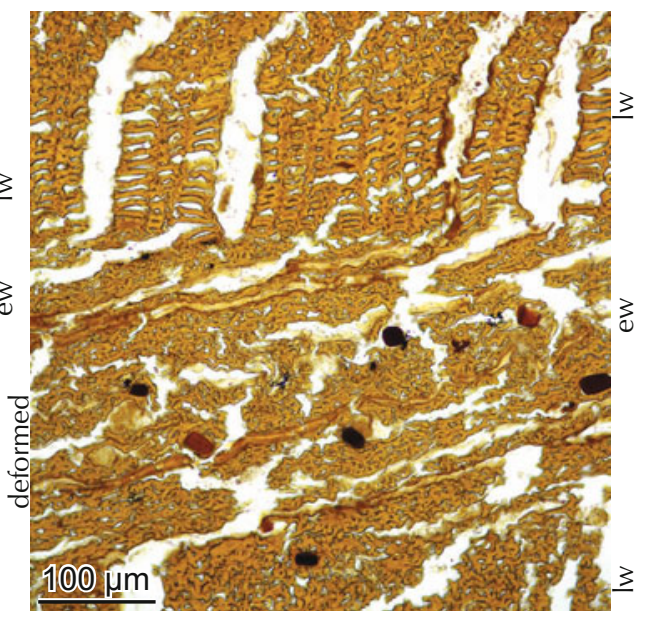

13.56 Intensively compressed earlywood and latewood zones in Sequoiadendroxylon sp. million years ago. 


\subsection{Carbonization}

Carbonization is the process of transforming wood into charcoal by pyrolysis. Charcoal used to be one of the most important energy resources in pre-industrial times because it was easy to transport. Most human civilizations produced charcoal in kilns, with the wood losing $50-70 \%$ of its weight. Charcoal burning and grazing were the main reasons for the depletion of ancient forests all over the world. With the switch to fossil fuels like coal and coal oil, charcoal lost some of its importance. It also used to be important for the production of gun powder (black powder). Today, charcoal is still widely used, e.g. for local metallurgic processes, chemical filtering, barbecues and charcoal crayons.

The carbonization process does not destroy the species-specific anatomical structures of the material. Also, charcoal is very stable against biodegradation in both dry and wet environments. Charcoal is therefore of relevance to historical studies, as ancient prehistoric fires-changing human behavior and vegetation patterns from the tropics to the arctic-can be documented with the identification of particles as small as a cubic millimeter.

During the carbonization process, cell walls shrink by approx. $50 \%$ and also lose their fibrillose structure. However, the structure of pits and perforations, and of artifacts caused during decay before the carbonization process, remain. Longitudinal cracks and tangential cell collapses are a sign of vapor pressure during the heating phase.

Binocular stereomicroscopes and episcopic microscopes facilitate the observations. Thin sections, embedded in two component epoxy resin, are the basis for photographic presentations (see Chapter 2).

\section{Charcoal production}

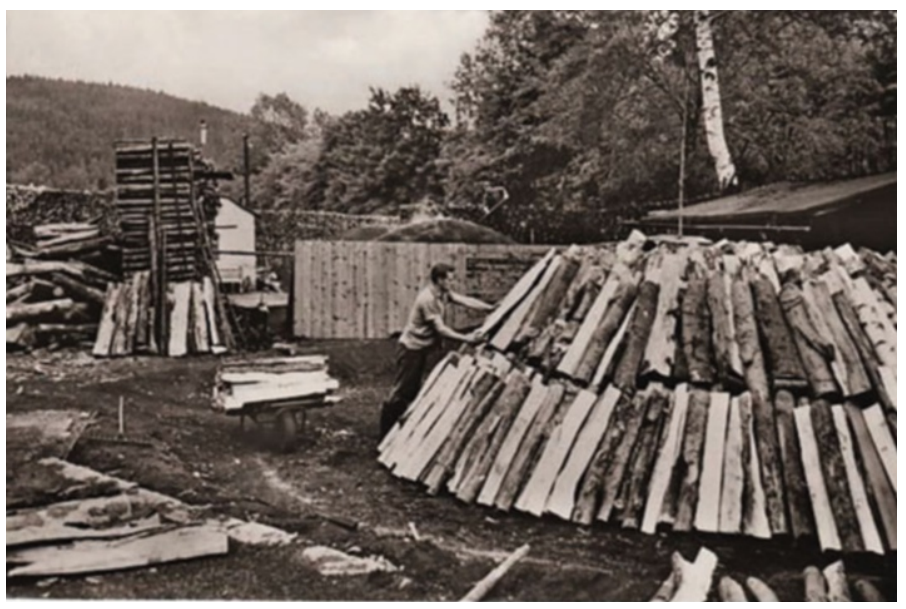

13.57 Establishment of a charcoal kiln in the Black Forest. Photo: T. Ludemann.

\section{Carbonization artifacts}

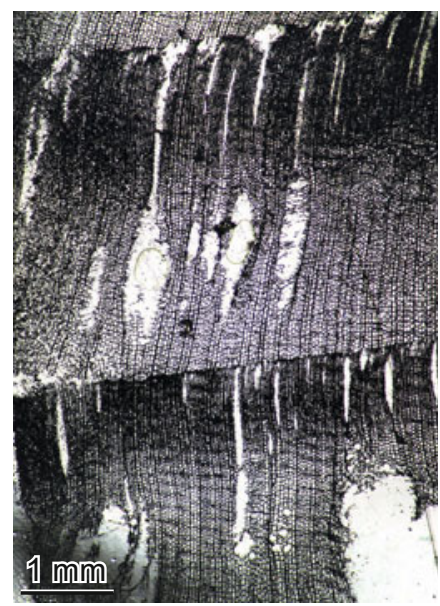

13.58 Radial cracks in this conifer are caused by vapor pressure during the heating phase.

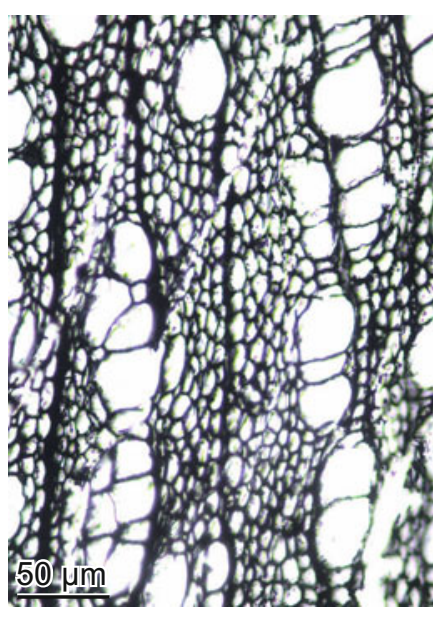

13.59 Thin carbonized cell walls in Alnus sp.

Species identification from anatomical structures preserved in charcoal

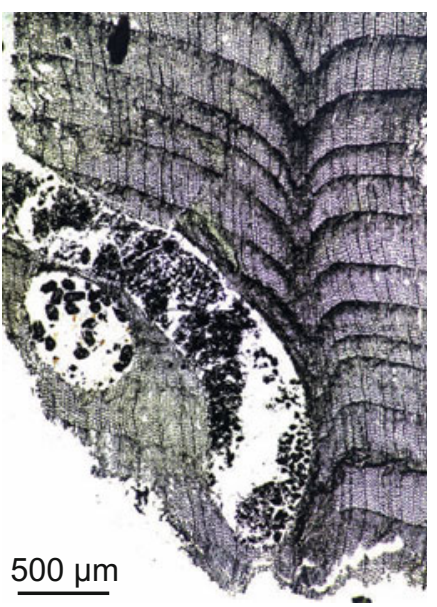

13.60 Conifer with an insect gallery, filled with coprolites.

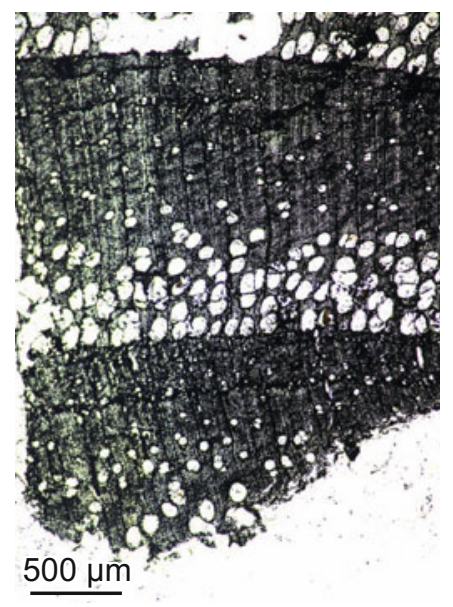

13.61 Charcoal cross section of Fraxinus excelsior.

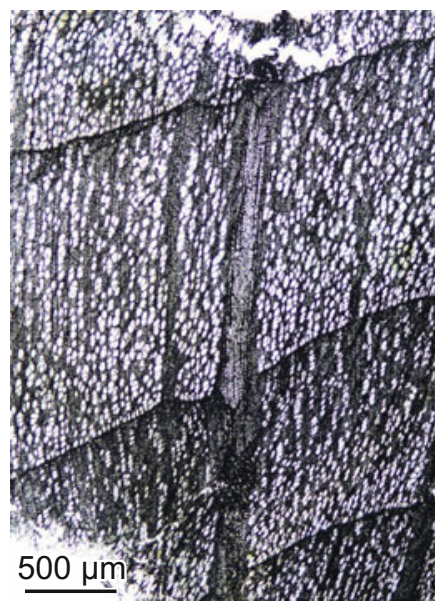

13.62 Charcoal cross section of Alnus sp.

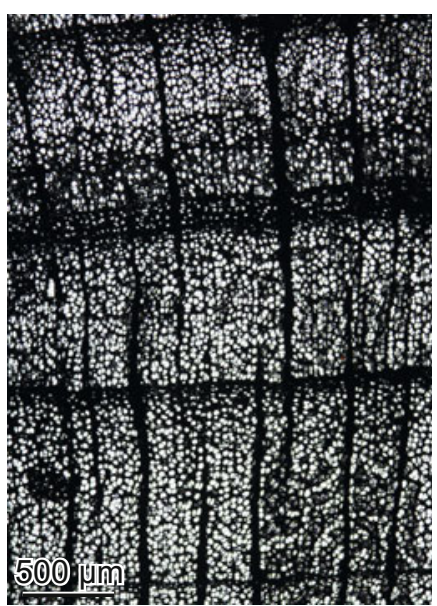

13.63 Charcoal cross section of Fagus sylvatica. 


\subsection{Wet wood conservation}

Woods in anoxic sediments can keep their form over millennia. However, decomposition takes place on a cellular level. Alterations become obvious when logs or archaeological artifacts dry out. Radial shrinking and weight loss are macroscopic signs of intensive decomposition, cell collapses are visible on a microscopic level. Despite many deformation artifacts, parts such as roots from plants along lake shores can be identified.

Natural preservation occurs in the heartwood of logs of pines soaked in resin, and of oaks with high levels of phenols. The central parts of stems resist decomposition at the air, but the sapwood decays. The situation is much worse in wood of lake dwellings. Most wooden artifacts are of small dimensions, and made mostly of wood of deciduous trees. Five-thousandyear-old Neolithic stems of deciduous trees with a diameter of $10 \mathrm{~cm}$ lose approximately $50 \%$ of their original weight, and shrink radially when dehydrated up to $80 \%$. Therefore a large part of human cultural heritage would be lost without artificial preservation. Archaeologists preserve the form of large artifacts mainly with polyethylene glycol (PEG), e.g. the Swedish warship Vasa. Smaller wooden instruments are preserved by freeze drying or dimethyl ether treatment. The form and superficial traces of human treatment of ancient wet wood can therefore be kept in museums. The cell wall structures of wet wood do survive preservation techniques.

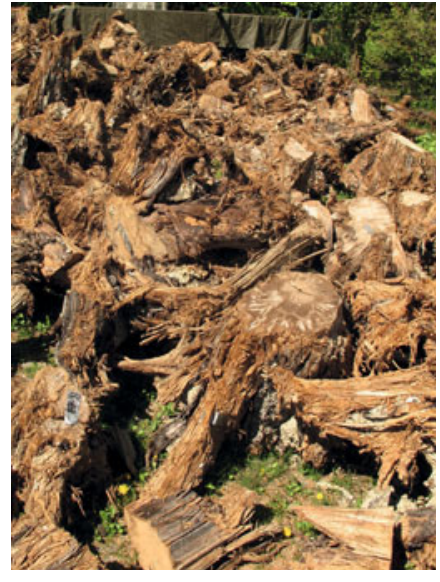

13.64 Late glacial stems of Pinus sylvestris that have been exposed to air. The stump surfaces decay and scientific information about the life of those trees is lost.

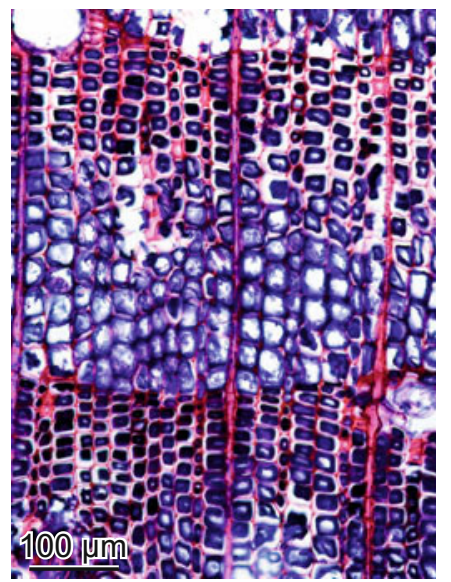

13.68 Not dehydrated, heavily degraded wood of late glacial Pinus sylvestris. The cell form and primary cell walls (red) remain. Secondary walls lost their original structure and are delignified (blue).

Macroscopic changes on wet wood after dehydration

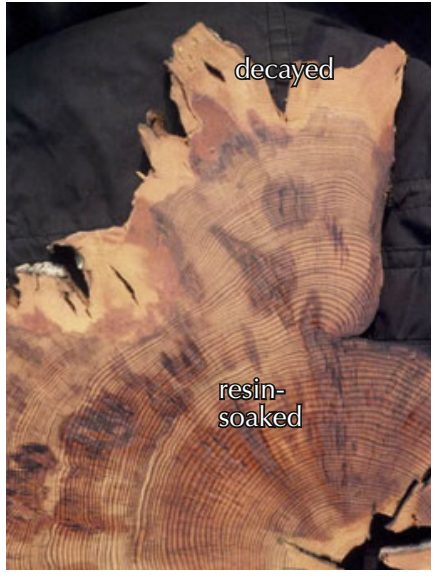

13.65 Disc of an air-exposed Pinus sylvestris stem. The large central part is preserved due to natural impregnation with resin. The peripheral zone without resin decays.

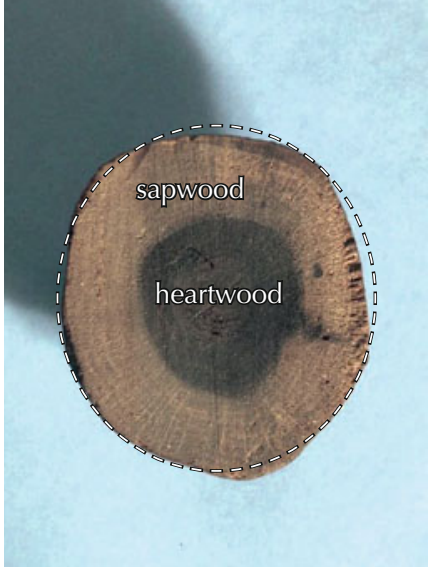

13.66 Disc of a water-saturated archaeological Quercus sp. Its form is perfectly preserved.

\section{Microscopic changes on wet wood after dehydration}

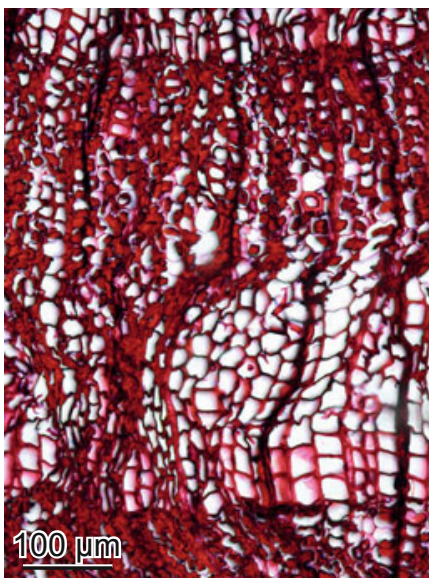

13.69 Dehydrated, heavily degraded wood of late glacial Pinus sy/vestris. Cells lost their original form due to contraction, and degraded secondary cell walls appear as unstructured bodies.

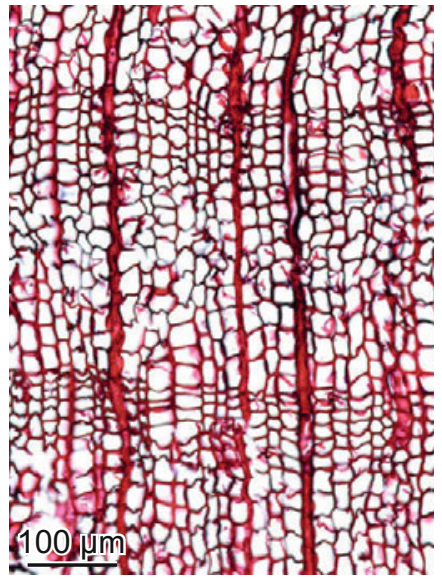

13.70 Dehydrated, heavily degraded wood of late glacial Pinus sylvestris. The cell forms remain, but the secondary walls are gone.

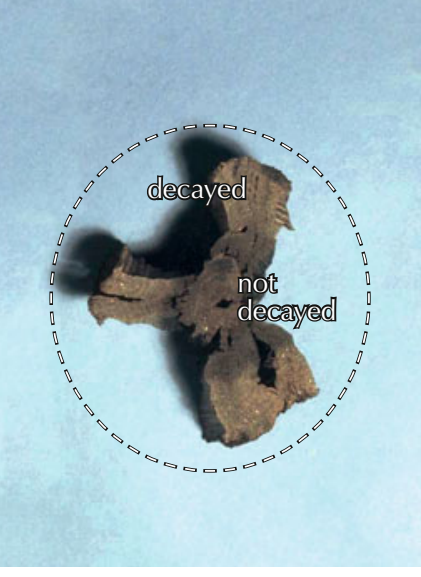

13.67 Disc of the same Quercus stem, but dehydrated. Intensively decayed parts shrink dramatically, as indicated by the original outline.

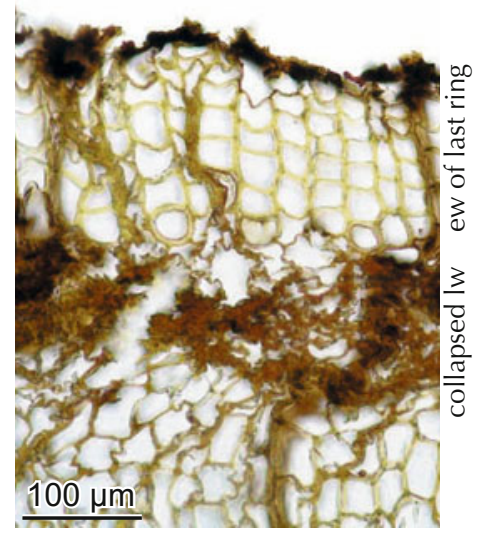

13.71 Dehydrated, heavily degraded wood of Pinus sylvestris. Latewood cells are collapsed, earlywood cells of the outer ring kept their form. The tree died during earlywood formation in early summer approx. 13,000 years ago. 
Microscopic changes on wet wood after dehydration

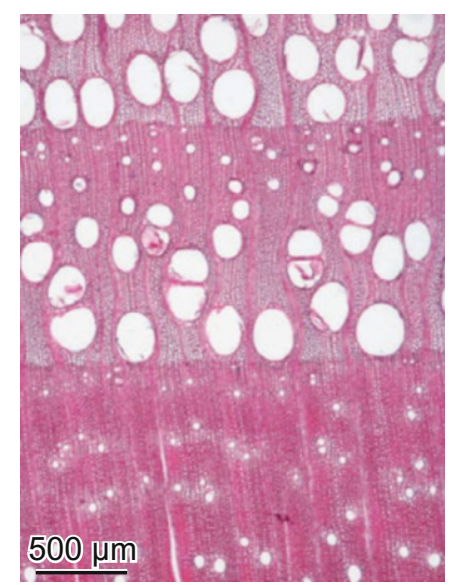

13.72 Modern wood of Fraxinus excelsior, stained with Safranin. All microscopic structures can be recognized.

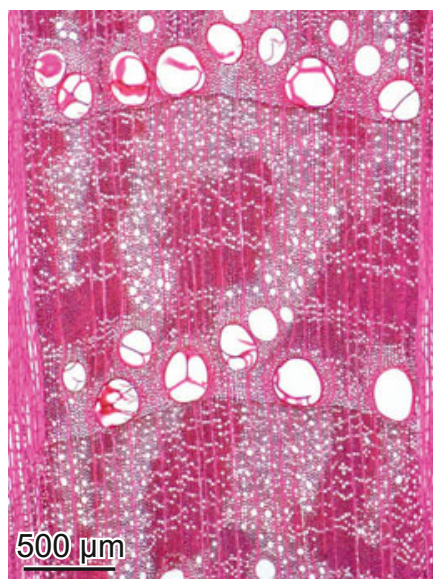

13.76 Modern wood of Quercus petraea, stained with Safranin. All microscopic structures can be recognized.

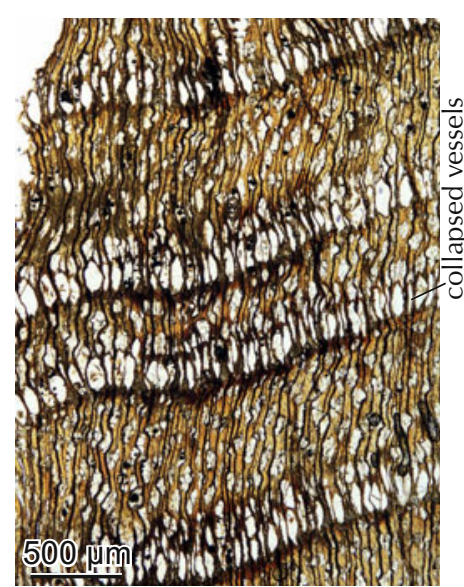

13.73 Dehydrated, heavily degraded wood of Neolithic Fraxinus excelsior. Lateral contraction deformed the original structure, but major anatomical characteristics for the species remain. collapsed vessels

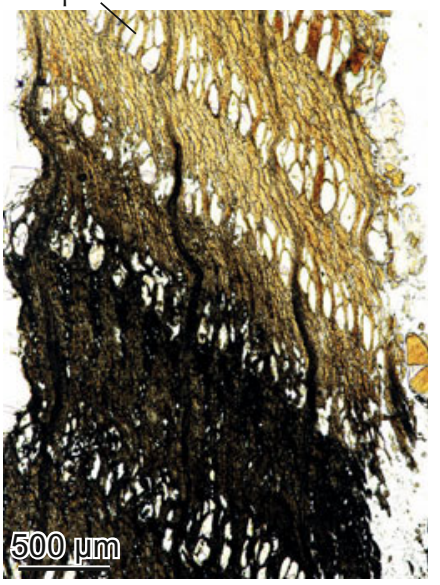

13.77 Dehydrated, heavily degraded wood of Neolithic Quercus sp. Lateral contraction deformed the original structure, but major anatomical characteristics for Quercus remain e.g. ring porosity, large rays, dark heartwood.

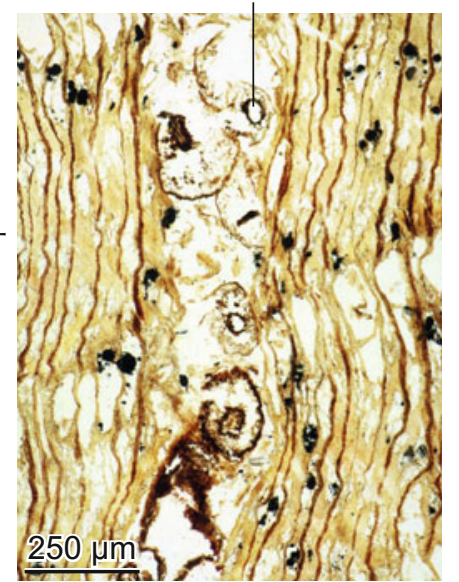

13.74 Dehydrated, heavily degraded wood of Neolithic Fraxinus excelsior. It maintained its anatomical structure despite some lateral deformation by roots from plants of the lake shore. parenchyma cell fiber

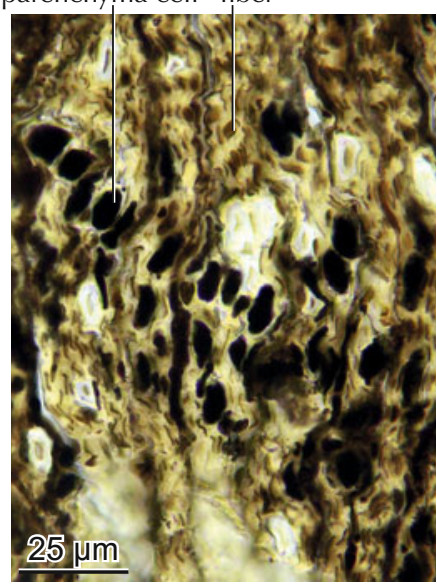

13.78 Dehydrated, heavily degraded wood of Neolithic Quercus sp. Alterations due to dehydration are specific to cell types. Fibers are heavily compressed, parenchyma cells with cell contents less so.

Effect of conservation

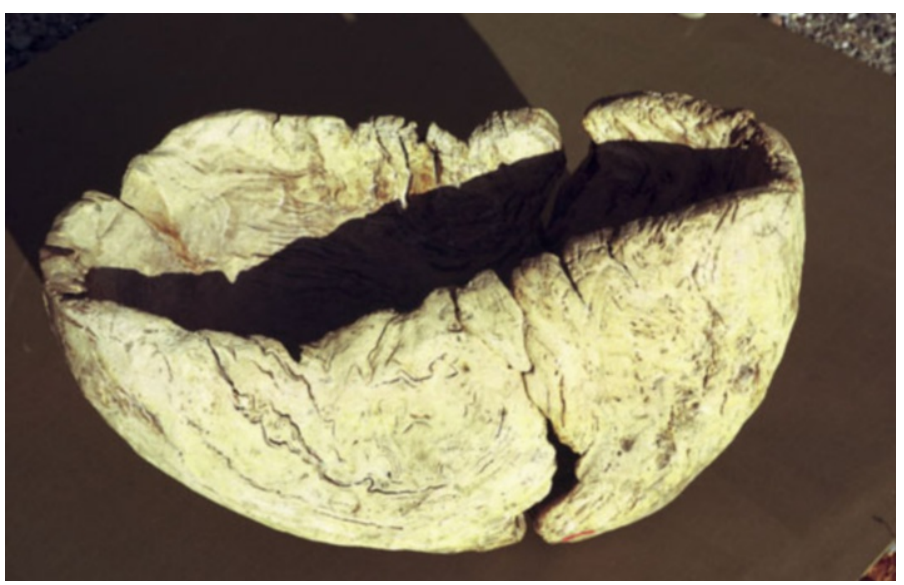

13.80 Neolithic wooden bowl conserved with diethyl ether resin.

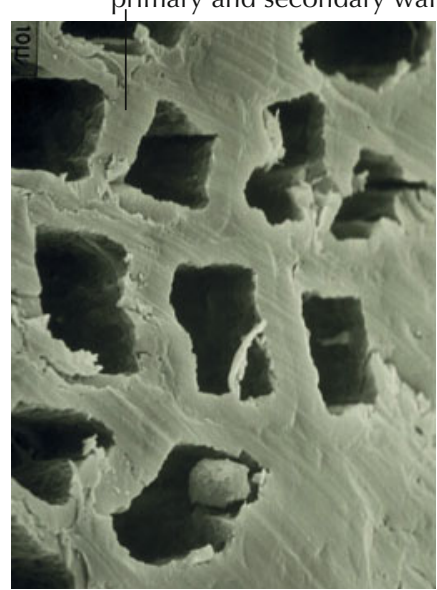

13.81 Cell walls without structure after freeze drying. Electron-optical photograph. Reprinted from Bräker et al. 1979.
Material: Swiss National Museum.

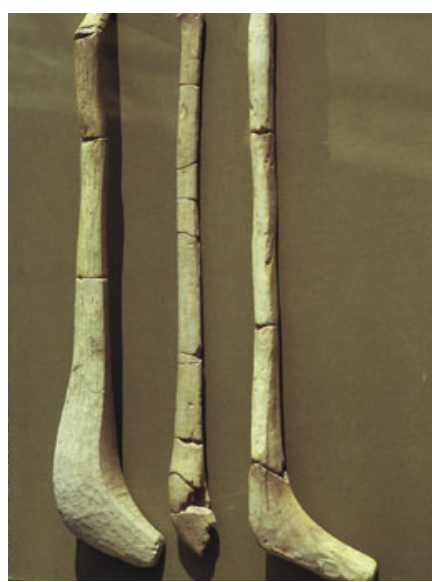

13.75 Dehydrated, heavily degraded wooden artifacts, made from Fraxinus excelsior, maintained their original form after conservation treatment by freeze drying.

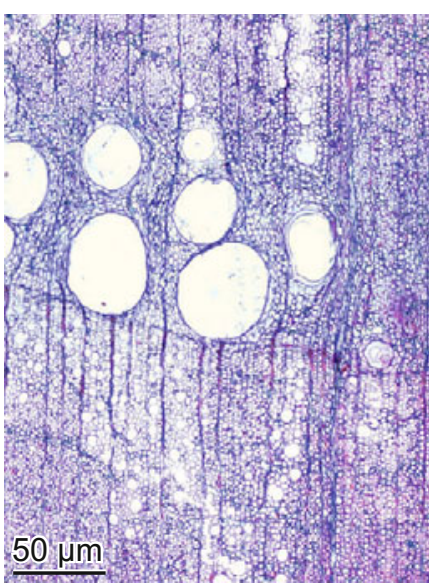

13.79 Well preserved anatomical structure of wood of Neolithic Quercus sp. after conservation treatment by freeze drying and polyethylene. Cell walls are decomposed.

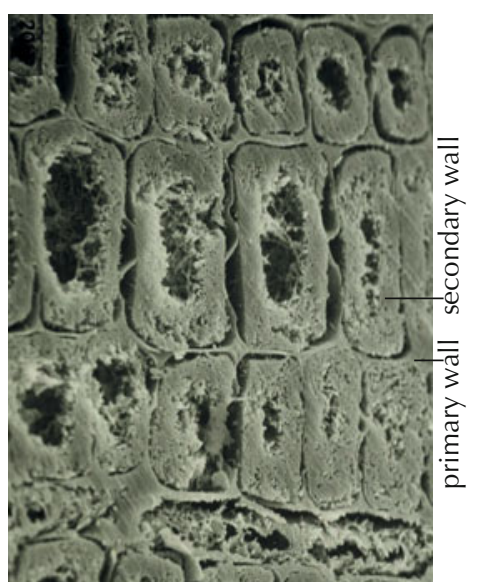

13.82 Partially preserved cell wall structure after diethyl ether treatment. Electron-optical photograph. Reprinted from Bräker et al. 1979. 
Open Access This chapter is licensed under the terms of the Creative Commons Attribution 4.0 International License (http://creativecommons.org/licenses/by/4.0/), which permits use, sharing, adaptation, distribution and reproduction in any medium or format, as long as you give appropriate credit to the original author(s) and the source, provide a link to the Creative Commons license and indicate if changes were made.

The images or other third party material in this chapter are included in the chapter's Creative Commons license, unless indicated otherwise in a credit line to the material. If material is not included in the chapter's Creative Commons license and your intended use is not permitted by statutory regulation or exceeds the permitted use, you will need to obtain permission directly from the copyright holder. 